\title{
Vaccination of C57BL/10 mice against cutaneous leishmaniasis using killed promastigotes of different strains and species of Leishmania
}

\author{
Vacinação de camundongos C57BL/10 contra leishmaniose com promastigotas \\ mortas de diferentes cepas e espécies de Leishmania \\ Wilson Mayrink ${ }^{1}$, Gilmara Cristina dos Santos' ${ }^{1}$ Vicente de Paulo Coelho Peixoto de Toledo², \\ Tânia Mara Pinto Dabés Guimarães², George Luis Lins Machado-Coelho ${ }^{3}$, \\ Odair Genaro and Carlos Alberto da Costa ${ }^{2}$
}

\begin{abstract}
Antigenic extracts from five Leishmania stocks were used to vaccinate C57BL/10 mice. The Leishvacin $®$ and PH8 monovalent vaccine yielded the highest IFN- $\gamma$ levels in the supernatants of spleen cell culture from vaccinated animals. Each single strain immunized group showed evidence of protective immunity six months after the challenge with promastigotes of Leishmania (Leishmania) amazonensis. No differences were detected between the vaccinated groups. It can be concluded that vaccines composed of single Leishmania stocks can provide protection to C57BL/10 mice against L. (L.) amazonensis infection.
\end{abstract}

Key-words: Leishmania. Vaccine. Interferon- $\gamma$. Interleukin-4.

Resumo Estudos anteriores revelaram que uma vacina preparada com promastigotas mortas de cinco cepas de Leishmania pode induzir uma imunidade protetora para a leishmaniose tegumentar americana no homem e em modelos experimentais. Um dos problemas do uso desta vacina é a complexidade de sua composição e a necessidade de se incorporar diferentes cepas de Leishmania. Por esta razão, extratos antigênicos de cada uma das cinco cepas constituintes da vacina foram preparados e usados individualmente em estudos imunológicos com camundongos C57BL/10. A Leishvacin ${ }^{\circledR}$ e a vacina monovalente PH8 induziram os maiores níveis de Interferon-g (IFN- $\gamma$ ) detectado no sobrenadante de células esplênicas dos animais vacinados. Cada grupo imunizado com vacinas monovalentes desenvolveram uma imunidade protetora seis meses após a infecção desafio com promastigotas de Leishmania (Leishmania) amazonensis e nenhuma diferença estatística foi observada entre os grupos vacinados. Pode-se concluir que vacinas compostas por cepas isoladas de Leishmania protegem camundongos C57BL/10 contra, pelo menos, da infecção por L. (L.) amazonensis.

Palavras-chaves: Leishmania. Vacina. Interferon-g. Interleucina-4.

Leishmaniasis are parasitic infections of animals and humans caused by several species of protozoans of the genus Leishmania. Cutaneous, mucocutaneous and visceral manifestations are clinically observed depending on the species involved and the host's response.

Visceral leishmaniasis is a serious form with a high mortality rate ${ }^{47}$, however, with treatment of patients, use of insecticides, elimination of dogs and epidemiological surveillance it is possible to control the transmission ${ }^{1526}$. On the other hand, prevention of the American tegumentary leishmaniasis (ATL) is difficult because it is a zoonosis whose vectors and reservoirs are mainly sylvestric $^{19}{ }^{34}$. Thus, the measures for identifying and combating the infected animals, as well as the use of insecticides, are difficult.

Considering this problem, World Health Organization experts admit that vaccination would be the only desirable, practical and safe measure for the control of tegumentary leishmaniasis ${ }^{34}$.

Attempts at human vaccination against cutaneous leishmaniasis have been tried in different parts of the world starting in the Old World 2738 . In Brazil the first trials were carried out by Pessoa \& Pestana ${ }^{40}$, with promising results, however 30 years elapsed until Mayrink et a ${ }^{R 9}$ continued these studies using a vaccine of dead promastigotes constituted of five Leishmania

1. Departamento de Parasitologia do Instituto de Ciências Biológicas da Universidade Federal de Minas Gerais, Belo Horizonte, MG. 2. Departamento de Análises Clínicas e Toxicológicas da Faculdade de Farmácia da Universidade Federal de Minas Gerais, Belo Horizonte, MG. 3. Departamento de Farmácia de Escola de Farmácia da Universidade Federal de Ouro Preto, Ouro Preto, MG.

Supported by BIOBRÁS SA and PRPq - Universidade Federal de Minas Gerais.

Address to: Dr. Wilson Mayrink. R. Equador 140/201, São Pedro, 30330-390 Belo Horizonte, MG,

e-mai:wilsonmayrink@uol.com.br

Recebido para publicação em 2/7/2001. 
strains, which were able to induce protection against ATL and did not show any side-effects ${ }^{3} 13283037$. Other recent researches support the Mayrink's findings. Thus, Mendonça et $a^{\beta 2}$ showed that humans, immunized against American tegumentary leishmaniasis using a vaccine made of whole antigens from killed promastigotes of five dermotropic Leishmania strains, had a positive proliferative response of peripheral blood mononuclear cells (PBMC) and Interferon-g was also detected in the supernatants of stimulated PBMC. Nascimento et $a^{\beta 7}$ vaccinated Brazilian army conscripts with polyvalent vaccine made of five Leishmania strains and found a correlation of $0 \%$ between positive skin test results and positive lymphocyte stimulation indices. This same vaccine has been shown to protect susceptible mice ${ }^{1213}$. Other animal models have been satisfactorily used. Kenney et $a /^{18}$ used rhesus monkeys to assess the safety, immunogenicity and efficacy of a vaccine combining heat-killed Leishmania (L.) amazonensis with rlL-12 and aluminum hydroxide gel as adjuvants. This study demonstrated the development of a protective immunity in primate model.

Despite these promising results, the complex composition of the vaccine (5 strains) has made it difficult to standardize as well as to identify those components that are responsible for inducing the specific immune response in vaccinated individuals. Thus, a "Vaccine
Advisory Group of Discussion" was organized and supported by World Health Organization in September 1991 in Belo Horizonte, MG, Brazil with the participation of representatives of national and international organizations interested in developing an anti-ATL vaccine. It was suggested that studies with the vaccine should continue, however using only one strain, the L. (L.) amazonensis (IFLA/BR/67/PH8). This strain was chosen because its antigens induced high stimulation indexes for lymphocytes from vaccinated volunteers it is easy to grow in noncellular media, it is internationally known and it is taxonomically well defined.

In addition, other studies have shown that the resolution of the lesions in mice, requires the induction of effective cell-mediated immunity against common antigens found in different strains of Leishmania 123942 . Because of this, it becomes relevant to produce individual antigenic extracts with each one of the 5 strains which are components of the vaccine described by Mayrink et al $1979^{29}$ and to carry out a comparative study of its immunogenicity using an animal model with the purpose of evaluating the humoral and cellular immunity as well as the immunoprotection induced by different vaccines facing the $L$. (L.) amazonensis challenge. Thus, we may define which strain(s) is (are) immunogenic by evaluating with immunological parameters.

\section{MATERIAL AND METHODS}

Parasites. The following strains were used to prepare the vaccines: L.(L.) amazonensis (IFLA/BR/67/PH8); L.(L.) mexicana (MHOM/BR/60/BH06); L.(Viannia) guyanensis (MHOM/BR/70/M1176); L. sp [(MHOM/BR/ 71/BH49) - L. major-like)]; L.sp [(MHOM/BR/73/BH121) - major-like)]. Promastigote cultures were initiated from biopsies of the border of leishmanial lesions in experimentally infected golden hamsters. They were grown in an NNN medium overlaid with LIT (NNN/LIT) culture medium ${ }^{7}$ at $23^{\circ} \mathrm{C}$. Infective promastigotes were obtained by the culture of hamster lesion fragments in an NNN/LIT medium at $23^{\circ} \mathrm{C}$ for 14 days. The challenge consisted of $1 \times 10^{5}$ L.(L.) amazonensis promastigotes.

Mice. Female C57B1/10 mice (8-12 week old) were obtained from the breeding facilities at the Instituto de Ciências Biológicas, Universidade Federal de Minas Gerais, Belo Horizonte, Minas Gerais state, Brazil, were used.

Preparation of vaccines. Vaccines were prepared according to previously described methods ${ }^{32}$. Briefly, promastigotes of five different stocks were grown separately in LIT medium and harvested at stationary phase ( 7 days of culture) by centrifugation. After washing with sterile saline, the pellet was divided in two: one part was disrupted by sonication and the other was then mixed and diluted with the appropriate amount of merthiolate phosphate buffered solution to give a final concentration of $240 \mathrm{mg} / \mathrm{ml}$ of total nitrogen ${ }^{20}$ and 1:10,000 merthiolate. In this way, five monovalent vaccines ( $\mathrm{PH} 8, \mathrm{M} 1176, \mathrm{BH} 06, \mathrm{BH} 121$ and $\mathrm{BH} 49)$ were prepared and the original Mayrink's polyvalent vaccine (Leishvacin $®)$ which is composed of all five strains.

Immunization of mice. Groups of 30 isogenic C57BL/10 mice per group were vaccinated according to Costa ${ }^{13}$. Each animal received two subcutaneous inoculations, at an interval of seven days, each dose containing $100 \mathrm{mg}$ of protein vaccine plus $250 \mathrm{mg}$ of Corynebacterium parvum. Twenty-eight days after the second dose, the animals received a further $10 \mathrm{mg}$ of vaccine, without adjuvant. Seven days after the booster, 10 animals were challenged with $1 \times 10^{5}$ L. (L.) amazonensis promastigotes inoculated subcutaneously into the base of their tails. The animals were examined at two-week intervals for a total of 180 days after the challenge to observe the appearance of lesions and their subsequent development. The 20 remaining animals were used to assess the humoral and cellular immune responses, seven days after booster. Ten mice were exclusively used for the delayed type hypersensitivity assay and ten other animals reserved to lymphocyte proliferation assay, evaluation of specific antibodies and cytokine quantification.

Controls. The control group consisted of mice that received only $C$. parvum with the same immunization schedule. Ten of them were challenged with $L$. (L.) amazonensis as described above and the ten remaining mice were used as control for immunological assays.

Humoral immune response. This was assessed by examining sera obtained 42 days after the first dose of 
vaccine, by ELISA, performed as described by Nascimento et $a^{\beta 7}$ using $2 \mathrm{mg} /$ well of the respective vaccine as an antigen, and goat anti-mouse $\lg G$ and IgM peroxidase conjugate (SIGMA, USA).

Cellular Immune Response. These evaluations were done 42 days after the first dose of vaccine.

Lymphocyte proliferation assay. Lymphocyte proliferation assays were performed as described by Costa et $a^{13}{ }^{13}$. Basically, spleen cells were harvested in an RPMI 1640 (SIGMA, USA) medium containing $10 \%$ fetal calf serum (SIGMA, USA), $2 \mathrm{mM}$ LGlutamine, $50 \mathrm{mM}$ 2-mercaptoethanol, 10,000 units of penicillin, $10 \mathrm{mg}$ streptomycin and $250 \mathrm{mg}$ fungizone (SIGMA, USA) per ml. Red blood cells were removed by lysis in a $0.144 \mathrm{M} \mathrm{NH}_{4} \mathrm{Cl}$ buffer. The cells $\left(4 \times 10^{5} /\right.$ well) were then incubated in triplicate in 96-well plates for 5 days either with $20 \mathrm{mg} / \mathrm{ml}$ of each vaccine antigens without merthiolate or $0.5 \mu \mathrm{g} / \mathrm{ml}$ of Concanavalin A (SIGMA, USA) in an atmosphere of $5 \% \mathrm{CO}_{2}$ at $37^{\circ} \mathrm{C}$. Proliferation was assayed by a $[3 \mathrm{H}]$ thymidine incorporation $(0.2 \mathrm{mCi} /$ well, specific activity $5.0 \mathrm{mCi} / \mathrm{ml}$ - Dupont, NEN Research Products, USA). The results were expressed as stimulation index. A positive response showed a stimulation index equal or higher than $2.5^{32}$. This assay was done with a cell pool from each group.
Cytokine quantification. A commercially available kit (Genzyme Corporation, USA, with $2.5 \mathrm{pg} / \mathrm{ml}$ of sensitivity ) for Interleukin-4 (IL-4) quantification was used to assay the levels of this cytokine on mononuclear cell supernatant harvested from splenic cell culture after a two-day stimulus with homologous Leishmania antigens. For IFN- $\gamma$ quantification in 72-hour mononuclear cell culture supernatant, we employed the same methodology previously described by Scott ${ }^{44}$. Dr. Phillip Scott (Pennsylvania University, USA) kindly provided the reagents. This assay has $2 \mathrm{pg} / \mathrm{ml}$ of sensitivity.

Delayed type hypersensitivity test. This test, which measures the footpad swelling test, was performed by the subcutaneous inoculation of $50 \mathrm{ml}$ containing $20 \mathrm{mg}$ of protein of the $\mathrm{PH} 8$ strain antigen in the sole cushion of the right paw of vaccinated mice ( $42^{\text {nd }}$ day), and the same volume of merthiolated saline was inoculated in the left paw $^{39}$. Measurements were performed at 24/48 hours after the inoculation with a micrometer (MITUTOYO, number 2046-08, Japan). The analyses of the right paw thickness (test) and of the left paw (control) were then compared, considering the mean difference between the footpads.

Statistical analysis. Analysis of antibody production in each group were made by paired two tail Student's t test. The remaining data were analyzed by univariated analysis and Scheffe's test. $P$ values $\leq 0.05$ were considered significant.

\section{RESULTS}

Evaluation of humoral immune response. According to Figure 1, we could verify that the immunization induced the production of anti-Leishmania antibodies with higher levels of $\lg M$ than of $\lg G$, in all immunized groups $(p<0.05)$, except in the group of mice which was vaccinated with LeishvacinÒ and in the control group.

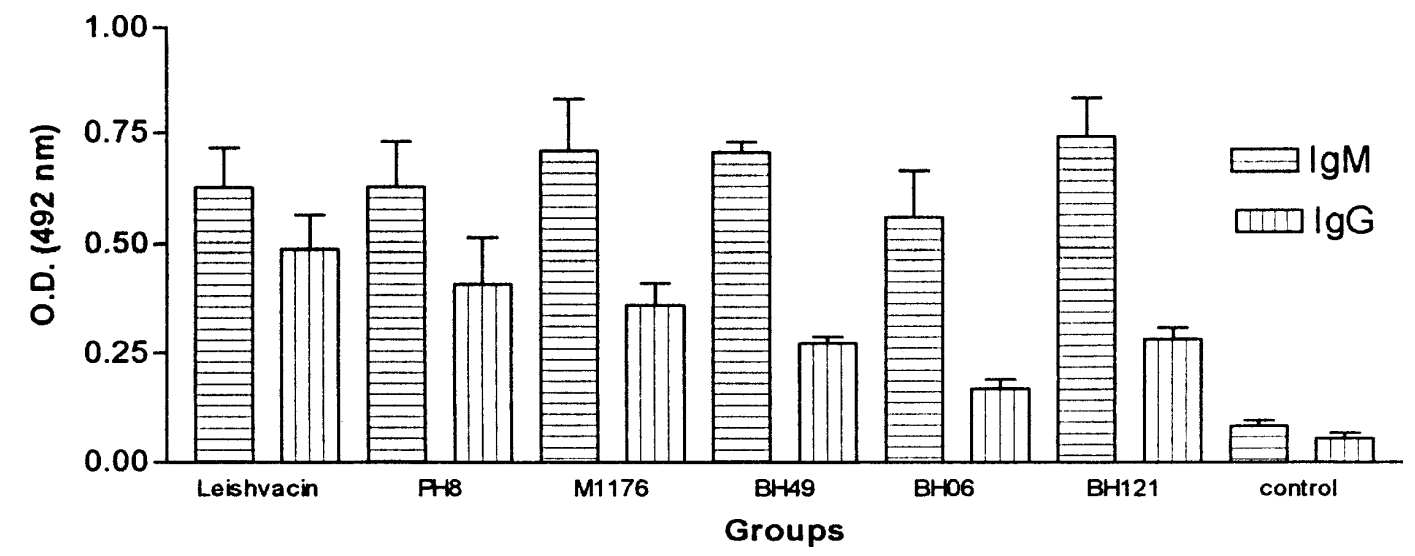

Figure 1 - Levels (mean $\pm S D$ ) of IgG and lgM detected in sera obtained from mice immunized with different vaccine formulations. Antibody levels were determined by ELISA using extracts of the promastigotes (2 $\mu \mathrm{gg} / \mathrm{well}$ ) of each strain. The data represent the absorbance of serum collected from 10 animals/group, at a dilution of 1/50. Control = serum of mice inoculated with C. parvum only. O.D. = Optical density. In all immunized groups, levels of IgM were always higher than lgG $(p<0.05)$. The error bars were represented in each column.

Test of Footpad Swelling Test. Ten animals in each group were inoculated with antigens of the parasite in the right paw and with merthiolated saline in the left paw, performing the analyses after 24 and 48 hours of inoculation and effectuating the difference among the swelling analyses of each paw. The mean of these differences between paws was determined. In Table 1 we observed that in the exam after 24 hours no statistically significant differences were noted between the mean size of swelling in the paws $(p>0.05)$ in all of 
the groups studied. Forty-eight hours after the antigen inoculation, we observed a reduction in relation to the analysis obtained after 24 hours, however without presenting significance ( $p>0.05)$. The analysis 2 days after inoculation was not different between any of the vaccinal groups $(p>0.05)$.

Table 1 - Footpad swelling test.

\begin{tabular}{lcr}
\hline & \multicolumn{2}{c}{ Reading after } \\
\cline { 2 - 3 } Groups & $24 \mathrm{~h}$ & \multicolumn{1}{c}{$48 \mathrm{~h}$} \\
\hline Leishvacin & $(\mathrm{n}=10)$ & $0.220 \pm 0.019$ \\
PH8 & $0.410 \pm 0.016$ & $0.360 \pm 0.036$ \\
M1176 & $0.470 \pm 0.033$ & $0.300 \pm 0.034$ \\
BH49 & $0.410 \pm 0.020$ & $0.210 \pm 0.023$ \\
BH06 & $0.430 \pm 0.037$ & $0.290 \pm 0.030$ \\
BH121 & $0.370 \pm 0.034$ & $0.270 \pm 0.030$ \\
Control & $0.420 \pm 0.034$ & 0 \\
\hline
\end{tabular}

The data represent the average of the differences $(\mathrm{mm})$ between the thickness of right foot (inoculated with antigen) and left foot (inoculated with saline solution). $\mathrm{N}=10$ mice per group. Values represent mean $\pm 1 \mathrm{SD}$
Lymphoproliferative response. In order to evaluate the level of cellular immunity induced by vaccination, groups of 10 mice $\mathrm{C} 57 \mathrm{BL} / 10$ were immunized with different Leishmania antigenic preparations plus $C$. parvum. Spleen cells from each immunized and control groups were incubated with the homologous antigen preparation. The proliferative response was measured by $[3 \mathrm{H}]$-Thymidine incorporation. Figure 2 shows that the specific antigen proliferation of spleen cells from immunized mice was at least 3.1 times higher than the one in control animals. All the ConA stimulated spleen cells always showed a stimulation index above 4.4 , suggesting that the culture cell system was carried out under good viability.

Evaluation of immunoprotection. C57BL/10 mice were immunized with different vaccinal preparations associated with $C$. parvum. The ability of each vaccine to induce a persistent protection in C57BL/10 mice against a challenge with $1 \times 10^{5}$ infective $L$. (L.) amazonensis promastigotes is presented in Figure 3.

cells stimtlated with Leishmania antigens

cells stimtlated ed with Con-A

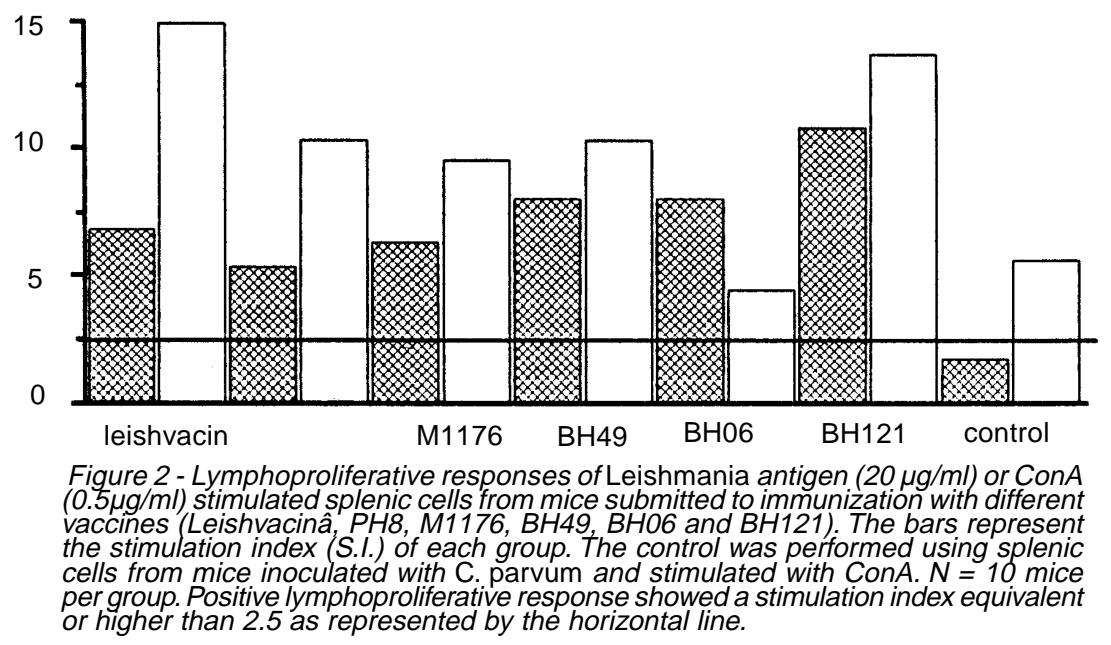

After the Leishmania inoculation, the animals were then followed-up for the appearance of lesions at the site of the inoculation (base of tail). The animals were considered protected when no lesion was observed. As shown in Figure 3, about 60 days after the challenge, almost $80 \%$ of control animals developed lesions (only at the site of the inoculation) compared with a maximum of $20 \%$ in the vaccinated group. After 150 days, about $40 \%$ of the animals in the vaccinated groups presented lesions. It should be mentioned that the lesions developed by vaccinated and non-protected mice were about ten-fold smaller than those in control animals (data not shown).

Cytokine quantification. In order to evaluate the cytokine production induced in C57BL/10 mice by the immunization with different isolated strains and the multivalent vaccine, we determined the cytokines through the immunoenzymatic reaction (ELISA), in the supernatants collected, after a 24 and 72-hour culture of splenic cells stimulated with homologous antigens of Leishmania for dosing IL-4 and IFN- $\gamma$ respectively. Figure 4 shows that all the vaccinated groups produced IFN- $\gamma$ in average levels higher than $570 \pm 141.72 \mathrm{pg} /$ $\mathrm{ml}$, with the animals vaccinated with Leishvacin $\AA$ and the monovalent vaccine $\mathrm{PH} 8$ presenting the highest levels of this cytokine, nevertheless there was no statistical difference between these two ( $p>0.05)$. On the other hand, these groups (Leishvacin ${ }^{\circledR}$ and $\mathrm{PH} 8$ ) produced a quantity of IFN- $\gamma$ which was significantly higher than the other vaccinal groups: M1176, BH06, $\mathrm{BH} 49$ and BH121 ( $<$ 0.05). Figure 5 shows that all 


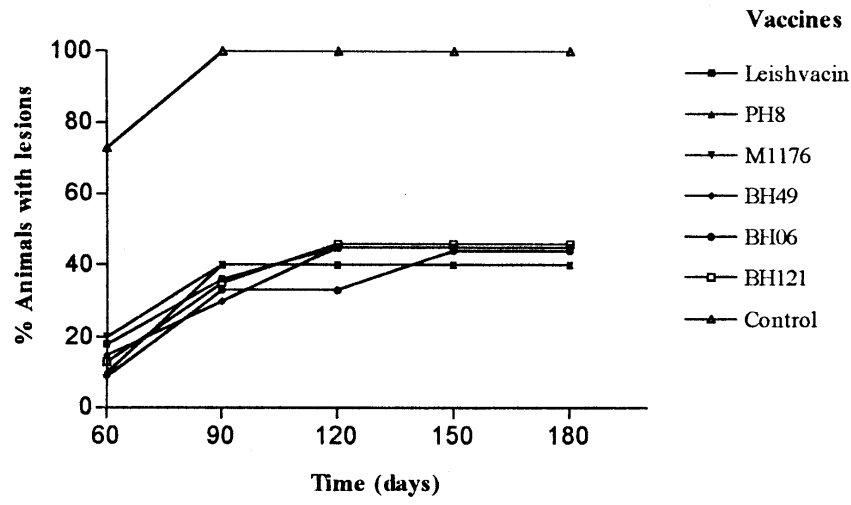

Figure 3 - Percentages of C57BL/10 mice immunized with different vaccines, developing leishmanial lesions after challenge by inoculation of promastigotes of L. (L.) amazonensis. Control represent animals inoculated with $\mathrm{C}$. parvum only. $\mathrm{N}=10$ mice per group. All immunized groups developed a significantly lower number of lesion than the control group $(p<0.05)$.

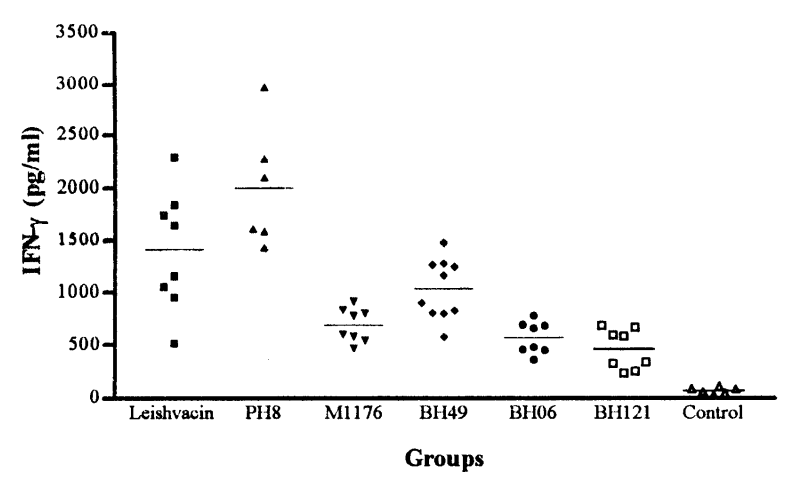

Figure 4 - IFN- $\gamma$ level $(\mathrm{pg} / \mathrm{ml})$ in the supernatant of homologous Leishmania antigen stimulated splenic cells from mice immunized with different vaccines (Leishvacin ${ }^{A}$, PH8. M1176, BH49, BH06 and BH121) for 72 hr to each animal. Horizontal bars represent the mean value for each group.

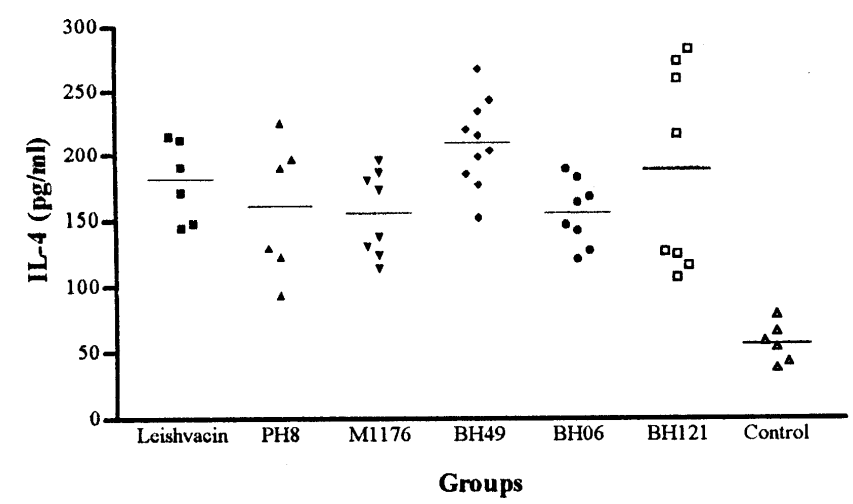

Figure 5 - IL-4 level $(\mathrm{pg} / \mathrm{ml})$ in the supernatant of homologous Leishmania antigen stimulated splenic cells from mice immunized with different vaccines (Leishvacin ${ }^{\circledR}$, PH8, M1176, BH49, BH06 and BH121) after $24 \mathrm{hr}$ for each animal. Horizontal bars represent the mean value for each group. 
groups produced consistently low and equivalent levels of $\mathrm{IL}-4(<210 \pm 32.56 \mathrm{pg} / \mathrm{ml})$ with no significant differences when compared among themselves $(p>0.05)$.

\section{DISCUSSION}

Besides the promising results obtained in the studies of vaccination against American tegumentary leishmaniasis developed a long time ago 293137 obtaining initially satisfactory results, the complexity of the vaccinal extract has made the process of industrialization difficult. This work, together with others related to the vaccination in humans ${ }^{32}$ gives the support which is necessary to solve this problem, since it enabled us to evaluate the immunogenic potential of each strain which constitutes the original vaccine.

The isogenic C57BL/10 mouse was used as it is susceptible to the infection with L.(L.) amazonensis. Costa $^{12}$, has shown that is possible to protect $50 \%$ of the animals by using the vaccine described by Mayrink et $a^{{ }^{29}}$ adding $C$. parvum as adjuvant. Later, Costa et $a^{l^{3}}$ observed that the vaccine industrialized by BIOBRÁS $S$. A. was equally effective in inducing immunoprotection against $L$.(L.) amazonensis. Posterior studies showed that the vaccine could be simplified by using only one strain in its composition ${ }^{30}$ as was suggested by the representatives of the organizations which participated in the "Vaccine Advisory Group of Discussion". Since then, studies have been realized using only one strain, the L.(L.) amazonensis (IFLA/BR/67/PH8). This work was performed with a view to finding the immunogenicity of each strain in isolation and through various immunological approaches.

Regarding the humoral immune response in the development of resistance to Leishmania, Mitchel ${ }^{33}$ showed that there is no clear evidence of the participation of antibodies in the protection against $L$. major in mice. Costa $^{12}$ showed in C57BL/10 that besides having found high levels of antibodies no relation was observed between these levels, cutaneous test and protection. On the other hand, several authors considered necessary an association of the cellular and humoral responses to establish the cure or resistance to the parasite. Among them, Preston \& Dumonde ${ }^{42}$ verified the transference of immune cells, together with immune serum, rendered CBA mice more resistant to $L$. major than it would be if the transference were made only with cells. Our results reveal that there was humoral immune response in all groups tested, with higher levels of IgM than of IgG which may be related to the immunization scheme adopted, similar to that employed by Nascimento et $a^{\beta 7}$ who also found high levels of IgM in the serum of patients vaccinated with Leishvacin $\AA$.

The correlation between delayed hypersensitivity and protective immunity in $L$. (L.) amazonensis was reported by Andrade et $a l^{2}$ who verified a persistent hypersensitivity in $\mathrm{A} / \mathrm{J}$ mice, considered resistant to this species while BALB/c are known to be susceptible. They observed a failure to establish this kind of response. Our data also showed an association between these two parameters. Grimaldi \& Moriearty ${ }^{16}$ observed that the analyses of the cutaneous tests after 24 hours presented a large infiltration of neutrophiles instead of mononuclear cells, which present a peak in 48 hours. Because of this, we also effected the analysis in this period, in which the intensity of the response was shown to be maller in relation to that at 24 hours, however with no differences in intensity of this response in the two points of analysis and in the different groups.

Recently, several studies have demonstrated that cellular immunity plays an important role in the cure of tegumentary leishmaniasis 8911143241 . Most of this knowledge was consolidated from the study of experimental infections in murine models ${ }^{14172324}$. Thus, in mice, the cure or resistance to the disease is directly related to the activation of macrophages with the production of nitric oxide to destroy intracellular parasites, with IFN- $\gamma$ and tumor necrosis factor - alpha (TNF- $\alpha$ ) as the main cytokines acting in this process ${ }^{1} 2246$. On the other hand, IL-4 and Interleukin 10 (IL-10) block this activity inhibiting the activation of macrophages, allowing the proliferation of intracellular amastigotes and the aggravation of the infection ${ }^{1421}$. In this model, the susceptibility of the BALB/c mouse is related to the induction of the immune response by CD4-TH2 cells while the resistance observed in CBA mice is associated to the induction of CD4-TH1 response ${ }^{23} 45$. This dichotomy between protective and non-protective immune response could be influenced by cytokine patterns produced by different lymphocyte subpopulations: Th1 producing mainly IFN- $\gamma$ and IL-2, while Th2 produces IL-4, 5 and $10^{36}$. Our results show that all vaccinal formulations induced lymphocytic proliferation. Or rather, splenic cells of vaccinated mice, after a specific in vitro antigenic stimulus, presented significant lymphoproliferation (stimulation index (SI) $>2.5)^{32}$. Our results also show that all vaccinal formulations stimulated T cells to synthesize IFN- $\gamma$ in vitro. It was demonstrated by variance analysis that $\mathrm{PH} 8$ and Leishvacin ${ }^{\circledR}$ induced equivalent levels of IFN- $\gamma$ $(p=0.446)$. Besides, PH8 induced more IFN- $\gamma$ than M1176, BH06, BH49, and BH121 vaccines $(p<0.05)$. Regarding IL-4, significant quantities were not found in any of the groups studied. This cytokine outline found suggests that the immunization of C57BL/10 mice with different strains of Leishmania leads to a significant stimulation of T cells with predominance of the Th1 type response. It is interesting to observe that, in this case, there was a cellular immune response against antigens of the extract of promastigotes of $L$. (L.) amazonensis developed by cells of animals immunized with the different strains of Leishmania in isolation, showing that all vaccinal formulations presented immunogenic potential similar to the immune response induced by the multivalent vaccine. 
However, both Leishvacin $\AA$ and the monovalent PH8 vaccine induced the highest levels of IFN- $\gamma$. This cytokine together with TNF- $\alpha$ are the cytokines which are responsible for establishing resistance to the parasite. another interesting result was observed when the animals which were immunized with the different strains of Leishmania were submitted to challenge: about $60 \%$ of the animals of all immunized groups were not infected, without any significant difference between the groups. This is a very important data, as the protection rate obtained was similar to that observed when the animals were vaccinated with the complex vaccinal extract $^{13}$. In similar studies, Preston \& Dumonde ${ }^{42}$ obtained protection against Leishmania tropica in CBA mice using sonicated promastigotes. In their model and in our experiments, some of the mice showed no lesions at all, while others had smaller lesions than those of the control animals. The reason for this partial protection is still unknown by us.

Finally, it must be highlighted that our data support the "Vaccine Advisory Group of Discussion" suggestion of Leishmania (L.) amazonensis to be the component of monovalent vaccine actually being tested in a clinical trial in humans, since its antigens elicited an immune response better or similar to the other Leishmania single strain vaccines used in this study.

\section{REFERENCES}

1. Afonso LCC, Scott P. Immune responses associated with susceptibility of C57BL/10 mice to Leishmania amazonensis. Infection and Immununity 61: 2952-2959, 1993.

2. Andrade ZA, Reed SG, Roters SB. Immunopathology of experimental cutaneous leishmaniasis. American Journal of Pathology 114: 137-148, 1984.

3. Antunes CMF, Mayrink W, Costa CA da, Magalhães P. Controlled field trial against New World Cutaneous Leishmaniasis. International Journal of Epidemiology 15: 572-580, 1986.

4. Barral A, Barral-Neto M, Young E, Brownell CE, Twardzik DR, Reed SG. Transforming growth factor $b$ as a virulence mechanism for Leishmania braziliensis. Proceedings of the National Academy of Sciences of the United States of America 90:3442-3451, 1993.

5. Berberian DA. Vaccination and immunity against oriental sore. Transactions of the Royal Society of Tropical Medicine and Hygiene 33: 87-94, 1939.

6. Button LL, McMaster WR. Molecular cloning of the major surface antigens of Leishmania. Journal of Experimental Medicine 167: 724-729, 1988.

7. Camargo ME. Growth and differentiation in Trypanosoma cruzi. I. Origin of metacyclic trypanosomes in liquid media. Revista do Instituto de Medicina Tropical de São Paulo 6: 93-100, 1964.

8. Carvalho EM, Johnson WD, Barreto E, Marsden PD, Costa JLM, Reed S, Rocha H. Cell mediated immunity in American cutaneous and mucosal leishmaniasis. Acta Tropica 56: 315-325, 1985.

9. Cástes M, Mara Z, Martinez A, Trujillo D, Castellanos PL, Rondon AJ, Convit J. Cell-mediated immunity in localized cutaneous leishmaniasis patients before and after treatment with immunotherapy or chemotherapy. Parasite Immunology 11: 211-222, 1989.

10. Champsi J, McMahon-Pratt D. Membrane glycoprotein M-2 protects against Leishmania amazonensis infection. Infection and Immunity 56: 3272-3279, 1988.

11. Conceição-Silva F, Dórea RCC, Pirmez C, Schubach A, Coutinho, SG. Quantitative study of Leishmania braziliensis braziliensis reactive $T$ cells in peripheral blood and in the lesions of patients with American mucocutaneous leishmaniasis. Clinical and Experimental Immunology 79: 221-225, 1990.

12. Costa CA. Infecção experimental do camundongo isogênico C57BL/10 com Leishmania mexicana amazonensis, estudos da atividade imunogênica de uma vacina com promastigotas mortas. Tese de Doutorado. Universidade Federal de Minas Gerais. Belo Horizonte, MG, 1986
13. Costa CA, Afonso LCC, Toledo VPCP, Tavares CAP, Genaro O, Mayrink W. Evaluation of an industrialized non-living promastigote vaccine against cutaneous leishmaniasis. Parassitologia 34: 4551, 1992.

14. Coutinho SG, Louis JA, Mavel J, Engers HD, Mavel J. Induction by specific $T$ lymphocytes of intracellular destruction of Leishmania major in infected murine macrophages. Parasite Immunology 6: 157-169, 1984.

15. Desjeux P. Human leishmaniasis: epidemiology and public health aspects. World Health Statistics Quarterly 45: 267-275, 1992.

16. Grimaldi GF, Moriearty PL. Kinetics and histopathology of the ear thickness test for delayed hypersensitivity in murine leishmaniasis. Revista do Instituto de Medicina Tropical de São Paulo 23: 127-132, 1981.

17. Howard JG, Hale C, Liew FY. Immunological regulation of experimental cutaneous leishmaniasis. III. Nature and significance of specific suppression of cell-mediated immunity in mice highly susceptible to Leishmania tropica. Journal of Experimental Medicine 152: 594-607, 1980.

18. Kenney RT, Sacks DL, Sypek JP, Vilela L, Gam AA, Evans-Davis $\mathrm{K}$. Protective Immunity using recombinant human IL-12 and alum as adjuvants in a primate model of cutaneous leishmaniasis. Journal of Immunology 163: 4481-4488, 1999.

19. Lainson R, Shaw JJ. The role of animals in the epidemiology of South American leishmaniasis. In: Lundsen WHR, Evans DA (eds) Biology of Kinetoplastidae, Academic Press, London, p.1-116, 1979.

20. Lang CA. Simple microdetermination of kjeldahl nitrogen in biological materials. Analytical Chemistry 30: 1962-1964, 1930.

21. Liew FY, Millot S, LiY, Lelchur R, Chan WL, Zitner H. Macrophage activation by interferon-gamma from host protective $T$ cells is inhibited by interleukin (IL-3) and IL-4 produced by diseasepromoting $T$ cells in leishmaniasis. European Journal of Immunology 19:1227-1232, 1989.

22. Liew FY, Parkinson C, Millott S, Savern A, Carrier MJ. Tumor necrosis factor (TNF a) In: Leishmaniasis. I.TNF a mediates hostprotection against cutaneous leishmaniasis. Immunology 69:570$573,1990$.

23. Locksley RM, Heinzel FP, Holaday BJ. Induction of $\mathrm{TH}_{1}$ and $\mathrm{TH}_{2}$ $\mathrm{CD}_{4}$ subjects during murine Leishmania major infection. Research in Immunology 142: 28-32, 1991.

24. Locksley RM, Heinzel FP, Sadick MD, Holiday BJ, Gardner KD. Murine cutaneous leishmaniasis susceptibility correlates with 
differential expansion of helper $\mathrm{T}$ cell subjects. Research in Immunology 138: 744-749, 1987.

25. Mayrink W, Antunes CMF, Costa CA, Melo MN, Dias M, Michalick MSM, Magalhães PA, Oliveira-Lima A, Williams P. Further trials of a vaccine against American cutaneous leishmaniasis. Transactions of the Royal Society of Tropical Medicine and Hygiene 80: 1001, 1986.

26. Magalhães PA, Mayrink W, Costa CA, Michalick MSM, Babá EH, Dias M, Mayrink W, Nascimento E, Williams P. Calazar na zona do Rio Doce, Minas Gerais: Resultados de medidas profiláticas. Instituto de Medicina Tropical de São Paulo 22: 197-202, 1980.

27. Marzinowsky El. L'immunité dans le bouton d'orient. Bulletin de la Societe de Pathologia Exotique 21: 638-641, 1928.

28. Mayrink W, Antunes CMF, Costa CA, Melo MN, Dias M, Michalick MSM, Magalhães PA, Oliveira-Lima A, Williams P. Further trials of a vaccine against American cutaneous leishmaniasis. Transactions of the Royal Society of Tropical Medicine and Hygiene 80: 1001, 1986.

29. Mayrink W, Costa CA, Magalhães PA. A field trial of a vaccine against American Dermal Leishmaniasis. Transactions of the Royal Society of Tropical Medicine and Hygiene 73: 385-387, 1979.

30. Mayrink W, Pinto JA, Costa CA da, Toledo VPCP, Guimarães TMPD. Evaluation of the potency and stability of a candidate vaccine against American Cutaneous Leishmaniasis. American Journal of Tropical Medicine and Hygiene 61: 294-295, 1999.

31. Mayrink W, Williams P, Costa CA, Dias M. An experimental vaccine against American dermal leishmaniasis: experience in the state of Espírito Santo, Brazil. Annals of Tropical Medicine and Parasitology 79: 259-269, 1985.

32. Mendonça SC, Coutinho SG, Amendoeira RR, Marzochi MCA, Pirmez C. Human American cutaneous leishmaniasis (Leishmania b. braziliensis) in Brazil: lymphoproliferative responses and influence of therapy. Clinical and Experimental Immunology 64: 269-276, 1986.

33. Mitchel GF. Host-protective immunity and its suppression in a parasitic disease: murine cutaneous leishmaniasis. Immunology Today 5: 224-226, 1984.

34. Modabber F. Experiences with vaccines against cutaneous leishmaniasis of men and mice. Parasitology 98: 549-560, 1989.

35. Mora AM, Mayrink W, Costa RT, Costa CA da, Genaro O, Nascimento E. Protection of C57BL/10 mice by vaccination with association of purified proteins from Leishmania (Leishmania) amazonensis. Revista do Instituto de Medicina Tropical de São Paulo 41: 243-248, 1999.

36. Mosmann TR, Coffman R L. Two types of mouse helper T-cell clone implications for immune regulation. Immunology Today 8: 223-227, 1987.

37. Nascimento E, Mayrink W, Costa CA da, Melo MN, Barros GC, Dias M, Antunes CMF, Lima MS, Taboada DC, Liu TY. Vaccination of humans against cutaneous leishmaniasis cellular and humoral immune responses. Infection and Immunity 58:2198-2203, 1990.

38. Nicole C, Manceaux L. Recherches sur le bouton d orient: cultures, reproduction experimentale, immunization. Annales de Institute Pasteur 24: 673-720, 1910.

39. Perez H, Pocino M, Malav I. Nonspecific immunodepression and protective immunity in mice infected with Leishmania mexicana. Infection and Immunity 32: 415-419, 1981.

40. Pessoa SB, Pestana BR. Ensaio sobre a vacinação preventiva na leishmaniose tegumentar americana com leptomonas mortas. Revista de Biologia e Higiene 10: 112-118, 1940.

41. Pirmez C, Cooper C, Paes-Oliveira M. Immunologic responsiveness in American cutaneous leishmaniasis lesions. Journal of Immunology 145: 3100-3104, 1990.

42. Preston PM, Dumonde DC. Experimental cutaneous leishmaniasis. V - Protective immunity in subclinical and self healing infection in the mouse. Clinical and Experimental Immunology 23: 126-138, 1976.

43. Russell D, Alexander J. Effective immunization against cutaneous leishmaniasis with defined membrane antigens reconstituted into liposomes. Journal of Immunology 140: 12741279, 1988.

44. Scott P. Host and parasite factors regulating the development of $\mathrm{CD}_{4}+$ subjects in experimental cutaneous leishmaniasis. Research in Immunology 142: 32-36, 1991.

45. Scott $P$, Kaufmann $S$. The role of T-cell subsets and cytokines in the regulation of infection. Immunology Today 12: 346-348, 1991.

46. Titus RG, Kelso A, Louis JA. Intracellular destruction of Leishmania tropica by macrophages activated with macrophage activating factor/interferon. Clinical and Experimental Immunology 55: 157-163, 1984.

47. World Health Organization - Expert Committee. Control of the leishmaniasis. Geneva, 1990. World Health Organization Technical Report Series 793. 